\title{
Ian McEwan's Characters in Žižekian Process of Subjectivity A Study of Ian McEwan's Atonement and Solar
}

\author{
Amir Barati (Corresponding author) \\ Faculty of English Language and Literature, Islamic Azad University of Tehran, Central Campus, Iran \\ E-mail: amirbarati@hotmail.com \\ Razieh Eslamieh \\ Department of English Language and Literature, Parand Islamic Azad University \\ E-mail: eslami_paranduniv@yahoo.com
}

Received: 14-08-2014

doi:10.7575/aiac.ijalel.v.4n.2p.120
Accepted: 17-10-2014

Published: 01-03-2015

\begin{abstract}
Jacques Lacan's (1901-1981) theory of subjectivity provides literary criticism with an authentic approach to the analysis of characters. Slavoj Žižek, also, supplies his own reading of the Lacanian theory by adding Hegel to the Lacanian Subject and generates his theory of 'subject in process.' Taken from Žižek's words that 'the status of the subject is thoroughly "processual"' (Žižek, 2010, p. 232), we have decided to call the Žižekian theory as processual subjectivity. Considering the psychoanalytic significance of the characters in the novels of the renowned British author Ian McEwan, we will apply the Žižekian theory of processual subjectivity on the main characters of Ian McEwan in two of his novels: Solar and Atonement. It is to be proved that this reading can lead to better appreciation and apprehension of characters' psyche.
\end{abstract}

Keywords: Subjectivity, Processual Subjectivity, Psychoanalysis, Ian McEwan, Slavoj Žižek

\section{Introduction}

Characters are the most crucial building-blocks of every fiction. That is the character whose presence gives livelihood and action to every tale. Major characters, minor characters, flat or round characters, stock characters, types, caricatures, and so on are only a few of the traditional terms used to formulate this literary phenomena (Hawthorn, 1997, p. 48). But as Roland Barth (1915-1980) says: "what is obsolescent in today's novel...is not the novelistic, it is the character; what can no longer be written is the Proper Name" (Rimmon-Kenan, 1983, p. 29). Barth is right, mostly when it comes to the realm of psychoanalytic criticism.

The mysterious (and in many cases psychotic) nature of the novels of the renowned British author Ian Russell McEwan (born on 21 June 1948) requires a non-traditional study and deep psychoanalytic analysis to uncover the reasons behind the thoughts and actions of his forensic characters. In this article, we are going to analyze two of his main characters in Atonement and Solar: Briony and Michael respectively. The two characters are the fruits of the new-wave McEwan who has taken a considerable distance from the initial Macabre (McEwan was dubbed Macabre due to the bitter, psychotic, bizarre and graphic nature of his early works).

Following a psychoanalytic criticism, every character can be considered as a subject who needs to be analyzed. Before the Slovenian philosopher and psychoanalyst Slavoj Žižek (born in 21 March 1949), Jacques Lacan (1901-1981) considered Oedipus as a psychoanalytic subject (Ellman, 1994, p. 10). For him, the subject was at the core of the theory and analysis (Rabaté, 2001, p. 16). But, many later critics failed to perceive this revolutionary look that Žižek revived in his criticism of literature, cinema and art (instances for this idea can be found in Žižekian readings of different novels and films in his book Enjoy Your Symptom! (1992)). Traditionally, psychoanalytic criticism is considered to focus on the psychic state of the author and the reader as well as the interrelations between them via text as a mediator. Charles E. Bressler in his Literary Criticism (1999) very loosely points that an analysis of a character is possible in psychoanalytic criticism and focuses on the notions of psychobiography and reader-oriented theories. A Handbook of Critical Approaches to Literature (1966) also notes that the main emphasis of psychoanalytic critics have always been focused on the author and the reader. Peter Brooks (1987) also fails to draw more attention to characters as subjects when he says:

I believe that we constitute ourselves as human subjects in part through our fictions and therefore that the study of human fiction-making and the study of psychic process are convergent activities and superimposable forms of analysis. (p. 334) 
Thus, Brooks fails to perceive the character as the biggest embodiment of the 'psychic process' in works of literature. Terry Eagleton is one of the few critics who has made a great attempt to reshape the subjects in literature and has talked about characters as subjects (See The Subject of Literature, 1985). Eagleton being a devout Marxist, though beautifully investigating the issue of human subjectivity in literature in comparison to the society, has also missed the psychoanalytic aspects of the issue.

Apart from the Barthian notion of the "process of nomination" (Rimon-Kenan, 1983, p. 36) and the subsequent focuses on the reader, in which the reader is considered as a part of the reading and the process of formation of the subject, the theories of Slavoj Žižek seems to be one of the only sources focusing mainly on the psychological statuses and actions of the character itself. Among all psychoanalysts, Žižek's theories seem to us the most helpful means to study McEwan's characters and acquire a better appreciation of the precious works of the great author.

\section{2. Žižek's Processual Subject}

To elaborate on the issue of subject and its inherent status, Žižek states that "the subject has no substantial actuality, it comes second, it emerges only through the process of separation, of overcoming its presuppositions" (Žižek, 2010, p. 232). The quote is revealing enough to show that Briony and Michael also go through the very same process to gain a kind of subjectivity.

Atonement (2001) begins at a rural house belonging to the Tallis family where Briony, her sister Cecilia, their mother, and their cousins live together. Her brother is away at university and the father is away at work. Briony is a talented teen-aged girl in love with fiction and writing. In the novel's words revealing the past, she "had no secrets" at all, but her desire to know more and her "imagination itself was a source of secrets" (McEwan, 2001, p. 5-6). She has "no secrets' reiterates the fact that she has no 'substantial actuality.' Briony is almost lost in the world of taken-for-granted childish ideas, family traditions, the bipolar world of the good and evil and the world of adulthood with all its conventions, many of which are unconventional for her.

Briony emerges through the Žižekian process of separation. This separation might be categorized to three crucial periods in the novel. The first is the separation from her childhood and stepping in the world of adulthood with no one around close enough to help her better understand the realm of adults. At a critical age passing her childhood and stepping in the realm of adulthood, Briony is neglected the acquaintance of her father, mother, brother and sister. Her father, Jack, is away at work. Mother Betty is almost always either taking care of the intense pressure of migraine or busy with doing the housework. Leon, Briony's brother, is having fun with classmates and ladies at university. Sister Cecilia is also busy with fantasizing the future plans, books, Robbie and her contemplations about the household and her future plans. Briony is almost an outcast. Her cousins, Lola, Jack and Pierrot, are also some kids unable to answer her questions. Lola being a little older than Briony, not only can help Briony, but also can help flourish her childish thoughts.

The second separation happens when Cecilia and Robbie leave home due to a horrible night's incident. At the night when Jack and Pierrot, missing their parents, flee from the Tallis house, Lola and the other people in the house go to find them. Lola is found by Briony while getting raped by an unknown man. Briony, being witnessed to the rape scene and having seen yet another sexual encounter between Cecilia and Robbie some hours ago, accuses Robbie of the rape attempt. Later on, the judge also charges Robbie for rape attempt, due to Briony's account and the love letter with a sensual tone she presents to the police which he had sent to Cecilia.

Because of Robbie's imprisonment, Cecilia leaves home and never turns back. The very separation from the two loved ones, her sister and her protective friend Robbie, caused Briony go through the very Žižekian process of separation and also that of "overcoming its presuppositions" (Žižek, 2010, p. 232). This process of atonement caused Briony overcome its presuppositions and as Žižek explicates, the very "presuppositions are also only a retroactive effect of the same process of their overcoming" (ibid). The horrible consequence of what she had done made her leave home, enter the nursing school and consequently serve at war.

The third separation is a detachment from the brutal reality she witnesses which is exactly a "retroactive effect of the same process of their overcoming" (ibid). After a separation from family and going to the nursing school and serving at war as a nurse, Briony's detachment from the old childish presuppositions lead her to confront life's harsh face. When Cecilia and Robbie, never having the love life they were seeking, both die at war, as a 'retroactive effect,' (ibid) Briony is obliged to overcome the reality and build a new fictional reality for herself to appease the atonal suffering.

Briony; the writer, fails again to maintain the fictional reality she had created and by expressing the reality behind her novel at the last segment of the novel, she does what Žižek inscribes as:

The result is thus that there is in both extremes of the process a failure or negativity inscribed into the very heart of the entity we are dealing with. If the status of the subject is thoroughly "processual," it means that it emerges through the very failure to fully actualize itself. This brings us once again to one possible formal definition of the subject: a subject tries to articulate ("express") itself in a signifying chain, this articulation fails, and by means of and through this failure, the subject emerges: the subject is the failure of its signifying representation. (Žižek, 2010, p. 232) 
A similar scheme can also be applied to Solar's Michael Beard. Michael, a middle-aged man of science, is in a desperate situation "immune to fresh experience" (McEwan, 2010, p. 4). On the contrary of Briony, who childishly craves for some new experiences, Michael is tired of new experiences and probably, in Žižekian terms, he is immune to the new failures resulting from the new experiences. "Misery was not simple for him" (ibid) anymore. Four times he failed in 'tidal' marriage and the fifth is also "disintegrating" (ibid, p. 3).

The story of Michael begins at such miserable point, when he is experiencing a hard failure; his love affair with his beloved wife is almost over. He is losing his object of desire, Beatrice, his young love who resembles Marilyn Monroe in the eyes of his friends. And the loss is too grave to bear, for she has affairs with their builder; a humble young and of course physically strong man. And the affair even gets more unbearably humiliating for him when it is happening at his own house before Michael's eyes. At nights, Michael in his "delusional state" (ibid 6) is experiencing her Laughter in the Dark (1960). He, lying on his bed, feels castrated and all the Noble Prize stuff of honor in physics cannot return her to his bed. "What impressed him was his ability to think of nothing else" (McEwan, 2010, p. 8).

Due to the frustrations caused by the previous failures in his love affairs, his age and his intense desire for his current wife while she is having affairs with another man, it takes time and energy from Michael to step out of the messy situation. As a subject, his status as a professor of physics and the fame he gained from the Noble Prize could not bring him any 'substantial actuality.' Michael also "emerges only through the process of separation" (Žižek, 2010, p. 232). His separation from Beatrice and desiring her, count as new beginnings for him to try a new life. Idealizing Beatrice had been a presupposition resulting from Michael's previous unsuccessful love affairs and overcoming this presupposition is 'only a retroactive effect of the same process of the overcoming' (ibid).

Like Briony who abandoned home and all the mess she had caused for the nursing school, Michael also separates from the mess at home and goes for his ideas and something he probably thinks has been successful, and that is physics. The subject, Michael, "tries to articulate ("express") itself in a signifying chain, this articulation fails, and by means of and through this failure, the subject emerges: the subject is the failure of its signifying representation" (ibid).

Michael, then in his miserable situation being lost as the result of the failure in his love affair, and also financially broke, goes through this process of signification. Being unable to "fully actualize" (ibid) himself by forming a family, he finds a new cause: climate change and the global warming, something almost strange to him.

"Beard was not wholly skeptical about climate change. It was in a list of issues, of looming sorrows, that comprised the background to the news, and he read about it, vaguely deplored it and expected governments to meet and take action." (McEwan, 2010, p. 15)

Michael comes across the issue at the new Center. "The Center is supposed to resemble the National Renewable Energy Laboratory" (ibid). Beard is appointed as the first head, but the real work is done through a senior civil servant named Jack Braby. Michael happens to visit a young rustic scientist called Tom Aldous at the Center. Playing the role of an apostle to Professor Beard, Tom becomes a new inspiration for Michael to continue following the new cause. In his first chat he told Michael that "he had applied to work at the Center because he thought the planet was in danger" and "excitedly assumed that the Center would have at its prime concern solar energy, particularly artificial photosynthesis and what he called nano-solar" (ibid, p. 24).

This simple inspiration becomes the prime idea around which Michael spends at least the next nine years of his life. After years of being away from scientific explorations and theorizations, Michael begins working hard on the issue. He visits teams of scientists and experts, lectures at academic institutes and universities and travels to the North Pole. The motivation is so high that almost overwhelms his whole life to the extent that he ironically and ideologically believes to be sacrificing himself for the sake of "science, (and) for the well-being of future generations" (ibid, p. 262).

The successful physicist by that time, who encounters many problems in the course of nine years and finally believes to be successfully developing new methods of acquiring energy to the world and consequently saving the earth, Michael is finally accused of the theft of knowledge and fraud and is arrested. A new failure happens to Michael but he, having his family around, seems not devastated when he "felt in his heart an unfamiliar, swelling sensation" of love (ibid, p. 279). The subject is emerging through the process of failures and that is the source of the swelling sensation.

Žižek considering the Hegelian notion of subjectivity assumes that:

The subject is not its own origin, it is secondary, dependant upon its substantial presuppositions; but these presuppositions do not have a substantial consistency of their own and are always retroactively posited. The only "absolute" is thus the process itself. (Žižek, 2010, p. 292)

Following Žižek's note, Michael's presuppositions change radically at least at two fundamental levels. In his personal life, being exposed to his inability to attract Patrice, he changes his presuppositions about his love relationship from being a lying womanizer having love affair with a tempting object of desire to owning a simple family with a simple woman and a lovely daughter. He goes through a long path to get to this point of presuppositions and this presupposition gains momentum at the last page of the novel and does not change at least till the end of the book. 
The second level is at science and physics. At first, Michael is skeptical about the issue of global warming and has just heard about it in the news outlets, but later on, he changes his presuppositions and sticks to the ideology that the earth is in danger of collapse. Believing in the 'planet earth in peril', in the whole course of the novel, Michael is looking for the issue and is in fact going through the path that Aldous had drawn. At the end of the novel, being arrested and charged for theft of researches made by Aldous before his death, Michael is probably forced to change his presupposition that the world might be in danger, but he is not the one savior.

Žižek then in his theories on the issue of substance in close relation to the subject states that:

"Substance is not only always already lost, it only comes through its loss, as a secondary return-toitself - which means that substance is always already subjectivized. In the "reconciliation" between subject and substance, both poles thus lose their firm identity." (ibid, p. 232)

The same process happens to Michael. For Michael, not only his presuppositions about the married life and physics alter radically at the end of the novel, as the result of which he 'loses his firm identity,' but also his substances lose their initial identity and differ radically. The perception of a married couple at the end of the novel alters greatly from the initial perception. The first married life with Patrice is of the official ceremony, while the second perception is of a much more tolerant and realistic desire to put up with the shortcomings of the spouse and trying to hold the family together at any cost by Melissa.

Also in the realm of physics, the perception regarding climate change and global warming and even a scientist's life in search of the truth in it radically changes from the initial perception concerning the world in danger of collapse. In the initial pages of the novel, there are many more signs of the apocalyptic vision rejected by Žižek as a cheap end of the world thought. This is changed to a much more refined way of consuming energy at the end of the novel. The substance of global warming loses its initial definition at the end of the novel and changes to a different phenomenon.

The same issue happens in Atonement (2001). The substances of love affair and even literature differ radically by the end of the novel. The didacticism of the initial Trials of Arabella is changed to the manipulations made in the novel of Atonement. The so-called vices of the world masterfully lose their identity. The traditionally-considered ill-marriage out of the wedlock loses its definition compared to the slaughters happened in the World War II. The childish substances lose their whole identity by the end of the novel.

The subjects, the spirits or the characters in both novels are trying to gain subjectivity by losing their initial status as well as their immediacy and come to themselves and flee from their previous selves to make a product of themselves as Hegel says and Žižek reiterates:

it is of the very nature of the spirit to be this absolute liveliness, this process, to proceed forth from naturality, immediacy, to absolute, to quit its naturality, and to come to itself, and to free itself, it being itself only as it comes to itself as such a product of itself; its actuality being merely that it has made itself into what it is. (Hegel, 1956, p. 7)

The two main characters are models for such Hegelian liveliness. The go through the process of subjectivity and do their best to gain a processual subjectivity through the very abandoning of naturality and freeing themselves from their status quos to gain their selves.

\section{Conclusion}

In this article we tried to present the processual nature of McEwan's subjects based on the theories of Žižek. The article worked at two levels, firstly to establish a new character analysis based on the psychoanalytic theory, and secondly to uncover new layers from McEwan's novels. The initial goal was achieved in the course of the article showing how perfectly the Žižekian processual subjectivity can fit into an analysis of the character in a literary novel. The later aim was achieved when more answers were found to the McEwanian clues. For instance, the answer to a simple question based on what is said in the article can sum up the whole issue of subjectivity in Atonement, and that is: Why, in Briony's last version of her autobiographical novel, the lovers survive? The justification that McEwan provides in support of his manipulation of their reality, is significant:

How could that constitute an ending? What sense or hope or satisfaction could a reader draw from such an account? Who would want to believe that they never met against, never fulfilled their love? Who would want to believe that, except in the service of the bleakest realism? I couldn't do it to them. I'm too old, too frightened, too much in love with the shred of life I have remaining... When I am dead, and the Marshals are dead, and the novel is finally published, we will only exist as my inventions. Briony will be as much of a fantasy as the lovers who shared a bed in Balham and engaged their landlady. No one will care what events and which individuals were misrepresented to make a novel...As long as there is a single copy, a solitary typescript of my final draft, then my spontaneous, fortuitous sister and her medical prince survive to love. (McEwan, 2001, p. 271) 
McEwan is right. The hopeful story with the love sensations is attractive to the reader, but there is another hidden reality behind Briony's efforts to save the lovers and that is the problem of subjectivity. The final draft is preferable for Briony and the reader due to the fact that it is lively and there is no end to the subject's process. One must read again the Žižekian quote (2010) from Hegel that "it is in the very nature of spirit to be this absolute liveliness, this process, to proceed fourth from naturality, immediacy..." (p. 230). The very process and liveliness is a predominant characteristic of the subject and therefore is preferable for all. This is another reason why old Briony is defending the last version irrespective of what in reality went on to them.

In Solar also the process of subjectivity was completely applicable. The subjectivity which Michael earned through the process of Global Warming researches and throughout the whole novel was significant in that he could finally gain what he needed. At the beginning, Michael was an old womanizer psychologically unaware of his need for a stable family life. Almost all his misery is coming from his desire for Patrice who is an object of desire. He has not come to terms that he must do something about his object of desire due to the fact that he does not have the facilities to pursue it. The other misery is that he is unaware of the fact that he is an old man psychologically and physically in need of reliance. Through the course of the novel he went to the process of subjectivity and came to terms with the revelation that he is in need of a family and at the end there happens to be seen an absolute subject in love with his child and relying on his family. The novel ends with many other people caring for him while in the beginning he was the one to care for others. The subject is absolute by the end of the novel.

\section{References}

Bressler, C. E. (1999). Literary Criticism: An Introduction to Theory and Practice (2nd ed.). Upper Saddle River, N.J.: Prentice Hall.

Brooks, P. (1987). The Idea of A Psychoanalytic Literary Criticism. Critical Inquiry, 13(2), 334.

Eagleton, T. (1985). The Subject of Literature. Cultural Critique, 2(2), 95.

Ellmann, M. (1994). Psychoanalytic Literary Criticism. London: Longman.

Evans, D. (1996). An Introductory Dictionary of Lacanian Psychoanalysis. London: Routledge.

Guerin, W. L. (1966). A Handbook of Critical Approaches to Literature. New York: Harper \& Row.

Hawthorn, J. (1997). Studying the Novel: An Introduction (3rd ed.). London: Arnold.

Hegel, G. W., \& Sibree, J. (1956). The Philosophy of History. New York: Dover Publications.

Rimmon-Kenan, S. (1983). Narrative Fiction: Contemporary Poetics. London: Methuen.

McEwan, I. (20022001). Atonement: A Novel. New York: N.A. Talese/Doubleday.

McEwan, I. (2010). Solar: A Novel. New York: Nan A. Talese/Doubleday.

Nabokov, V. (19601938). Laughter in the Dark (New ed.). New York: New Directions.

Rabate, J. (2001). Jacques Lacan: Psychoanalysis and the Subject of Literature. Houndmills, Basingstoke, Hampshire: Palgrave.

Žižek, S. (1992). Enjoy Your Symptom!: Jacques Lacan in Hollywood and Out. New York: Routledge.

Žižek, S. (2010). Living in the End Times. London: Verso. 